Roland Marcin PANCERZ OFM

(Kalwaria Zebrzydowska, WSD)

\title{
CHRZEŚCIJANIN A DOBRA MATERIALNE W REFLEKSJI SZKOLY ALEKSANDRYJSKIEJ: OD KLEMENSA DO DYDYMA
}

Pytanie o stosunek człowieka do dóbr materialnych pojawia się chyba w każdej religii. Każdy człowiek żyje bowiem w świecie materialnym i dla dobra prywatnego czy społecznego musi posługiwać się dobrami materialnymi. Pierwszą chrześcijańską ocenę tychże dóbr znajdujemy oczywiście w Ewangelii. Jedna $\mathrm{z}$ centralnych wypowiedzi Chrystusa na ten temat, to znany epizod o bogatym młodzieńcu (Mk 10, 17-27; Mt 19, 16-26; Łk 18, 18-27). Jego zakończeniem są twarde słowa Zbawiciela: „Jak trudno jest bogatym wejść do królestwa Bożego [...]. Łatwiej jest wielbłądowi przejść przez ucho igielne, niż bogatemu wejść do królestwa Bożego". Podobnie inne ustępy Ewangelii: kazanie na górze (Łk 6, 24), przypowieść o Łazarzu i bogaczu (Łk 16, 19-31) oraz o nierozważnym bogaczu (Łk 12, 16-21) ukazuja przede wszystkim niebezpieczeństwo, jakie płynie z posiadania i przywiązania do dóbr materialnych. Ogólnie rzecz biorąc, z Ewangelii wyłania się obraz dóbr tego świata jako rzeczy wysoce niebezpiecznej dla zbawienia człowieka. Znacznie łagodniejszym tonem przemawiają natomiast Listy Apostolskie, na przykład 1Tm 6, 17-19.

Próby rozwiązania problemu podejścia chrześcijanina do dóbr materialnych w literaturze wczesnochrześcijańskiej idą w różnych kierunkach. Już na przełomie I i II wieku można zaobserwować ukształtowanie się dwóch tendencji. Pierwsza z nich - pojawia się w apokryfach, w środowiskach gnostyckich - akcentuje, że uczeń Chrystusa musi radykalnie uwolnić się od dóbr materialnych i od relacji ze światem, aby pójść za Chrystusem; powinien radykalnie naśladować ubóstwo swego mistrza. Ubóstwo jest tu pojmowane jako cnota, a posiadanie bogactw zostaje utożsamione z grzechem. Człowiek bogaty zostaje potępiony, a rezygnacja $z$ dóbr nie łączy się tu nigdy z solidarnością wobec ubogich. Druga tendencja - ta z kolei odpowiada pismom Ojców Apostolskich - akcentuje polecenie Jezusa, aby rozdawać swe dobra ubogim. Tutaj zatem nie tyle mówi się o dosłownym naśladowaniu Jezusowego ubóstwa, co raczej o naśladowaniu Jego miłości do ubogich i potrzebujących, a ubóstwo samo w sobie nie jest postrzegane jako cnota, lecz raczej jako rzecz, której trzeba zaradzić1.

\footnotetext{
${ }^{1}$ Por. E. dal Covolo, Chiesa - società - politica. Aree di , laicità” nel cristianesimo delle ori-
} 
W naszym artykule przyjrzymy się ocenie dóbr materialnych i człowieka bogatego w oczach czołowych przedstawicieli słynnej Szkoły Aleksandryjskiej². O ile poglądy Klemensa i Orygenesa w tej kwestii zostały już w jakiś sposób omówione w licznych publikacjach ${ }^{3}$, to właśnie stanowisko Dydyma, ostatniego nauczyciela tejże szkoły, nie doczekało się jeszcze osobnego opracowania.

1. Klemens Aleksandryjski. Porusza on nasze zagadnienie przede wszystkim w dziełku Quis dives salvetur?, gdzie koncentruje się wokół interpretacji wspomnianego już epizodu ewangelicznego o bogatym młodzieńcu, a także w kilku fragmentach dzieła Paedagogus. $\mathrm{Z}$ tego pierwszego pisma dowiadujemy się, że krążyły wówczas błędne poglądy, jakoby dla ludzi bogatych nie było możliwe przylgnięcie do chrześcijaństwa i w konsekwencji zbawienie wieczne; wielu bogatych musiało się $\mathrm{z}$ tego powodu zniechęcić i załamać4. Klemens adresuje więc swe dziełko do bogatych chrześcijan Aleksandrii a historia mówi, że byli oni wówczas liczni, bo miasto to należało wtedy do największych i najbogatszych w Cesarstwie oraz oferowało wysoki komfort życia - aby ich pocieszyć, uspokoić i zapewnić, że zbawienie, choć pod pewnymi warunkami, stoi jednak dla nich otworem ${ }^{5}$. Dziełko to zresztą nie zostało napisane $\mathrm{w}$ formie dylematu, czy bogaty może się w ogóle zbawić, jak zdawałby się sugerować tytuł. Dla naszego Autora jest bowiem oczywiste, iż Bóg w Jezusie Chrystusie zaoferował zbawienie wszystkim. Dziełko Klemensa jest raczej pytaniem o „duchową fizjonomię" bogatego chrześcijanina, odpowiadając na pytanie, jak ma wyglądać, jak powinien postępować zamożny chrześcijanin 6 . Trzeba podkreślić, że Aleksandryjczyk bardzo umiejętnie kieruje swe pouczenie do zamożnych, z jednej strony sprzeciwiając się potępianiu ich $a$ priori, z drugiej głoszeniu im próżnych pochwał, mogących ich utwierdzić w zbytkownym życiu i oddalić od zbawienia?

\footnotetext{
gini, Roma 1994, 42-44.

${ }^{2}$ Mówiąc o Szkole Aleksandryjskiej, zgodnie z panującymi obecnie opiniami nie rozdzielamy drastycznie działalności dydaktycznej Orygenesa i tej przed nim. Jakkolwiek za Orygenesa dokonało się połączenie tejże szkoły z instytucją episkopatu aleksandryjskiego, to jednak można mówić o pewnej kontynuacji działalności takich nauczycieli, jak Pantajnos i Klemens: por. E. Prinzivalli, Magister Ecclesiae. Il dibattito su Origene fra III e IV secolo, Roma 2002, 34-35.

${ }^{3}$ Dotyczy to szczególnie Klemensa, którego myśl wciąż spotyka się z zainteresowaniem ze strony uczonych: ostatnio zob. np. M. Paternoster, „Quis dives salvetur?” La salvezza nel contesto tipologico dell'opera di Clemente alessandrino, „Augustinianum” 47 (2007) 245-258.

${ }^{4}$ Por. Clemens Alexandrinus, Quis dives salvetur 2, 2; 3, 1; 27, 1, ed. O. Stählin - L. Früchtel - U. Treu, GCS 17, Berlin ${ }^{2} 1970,160-161$ i 177.

${ }^{5}$ Por. M.G. Mara, Ricchezza e povertà nel cristianesimo primitivo, Roma 1980, 35 i 43; Dal Covolo, Chiesa-società - politica, s. 53 i 55.

${ }^{6}$ Por. M.G. Bianco, Clemente Alessandrino, Quale ricco si salverà?, Roma 1999, 7-8, z przypisem 7 .

${ }^{7}$ Por. Clemens Alexandrinus, Quis dives salvetur 1, 1-3, GCS 17, 159-160.
} 
Jak więc Klemens interpretuje trudne słowa Jezusa: „Idź, sprzedaj wszystko co masz"? Otóż nasz Autor zauważa przede wszystkim, że słowa te nie

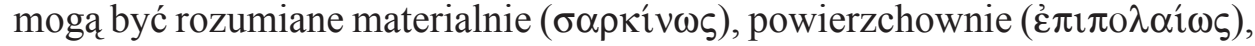
czy też w znaczeniu pospolitym ( $\pi \rho \circ \chi \varepsilon i ́ \rho \omega \varsigma)$, lecz poprzez odpowiednie poszukiwanie trzeba odkryć sens w nich ukryty. Słowa nauczania Jezusowego są „okryte cudowną i niebiańską głębią znaczenia”, wymagają zatem, by czytelnik odpowiednio je zgłębił ${ }^{8}$.

Klemens podaje zresztą szereg innych powodów, dla których polecenie Jezusa nie może być rozumiane dosłownie. Otóż gdybyśmy polecenie, aby pozbyć się wszelkich dóbr, rozumieli dosłownie, to żebracy, którzy być może w ogóle nie znają Boga, byliby najszczęśliwsi, najbardziej umiłowani przez Boga i jedyni mający życie wieczne? ${ }^{9}$ Samo zewnętrzne pozbycie się dóbr materialnych nasz pisarz ukazuje jako ambiwalentne ${ }^{10}$. Może ono bowiem być podyktowane różnymi przyczynami. Wielu, już przed przyjściem Chrystusa, uczyniło to także dla wiedzy, a nawet dla próżnej chwały, czy dla popularności $^{11}$. Ale tacy ludzie - zauważa Aleksandryjczyk - choć zewnętrznie pozbyli się bogactwa, to jednak w ich sercach pozostały namiętności: pycha, próżność, czy pogarda wobec innych. Zresztą ktoś, kto pozbył się dóbr, może przecież ciągle ich pragnąć i smucić się z powodu ich braku ${ }^{12}$. Najbardziej wymowne wydaje się tu lakoniczne stwierdzenie Klemensa: Nie ma pożytku, jeśli ktoś stał się ubogi w bogactwach, lecz pozostał bogaty w namiętności $(\pi \lambda \mathrm{ov} \tau \hat{\omega} \mathrm{v}$ $\tau \hat{\omega} v \pi \alpha \theta \hat{\omega} v)$ : zupełne ogołocenie się $\mathrm{z}$ dóbr materialnych może spowodować nawet sytuację paradoksalną: podsycenie ognia naszych złych żądz ${ }^{13}$.

Ponadto - rozważa nasz Autor - jest niemożliwe, żeby ktoś, kto pozbawiony jest rzeczy koniecznych do przeżycia oraz ciągle niepokoi się i troszczy o nie, zajął umysł rzeczami bardziej wzniosłymi ${ }^{14}$. I wreszcie Klemens dodaje chyba najbardziej praktyczny argument: Kto będzie wspierał ubogich, jeśli wszyscy będą pozbawieni wszelkich dóbr? Taka sytuacja sprzeciwiałaby się innym nakazom Pana: by nakarmić głodnych, przyodziać nagich, przyjąć do domu bezdomnych, itp. Sam zresztą Chrystus był gościem u Zacheusza, czy Mateusza, ludzi bogatych, i nie polecił im pozbyć się kompletnie dóbr, lecz tylko wyeliminować zysk niesprawiedliwy ${ }^{15}$. Z powyższych zatem powodów polecenie Jezusa: „Idź, sprzedaj wszystko co masz”, Klemens rozumie alegorycznie: słowa te nakazują by wyeliminować namiętne żądze

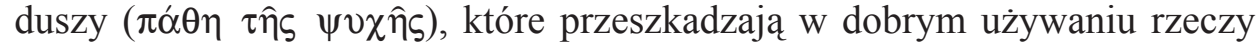

\footnotetext{
${ }^{8}$ Por. tamże 5, 2-4; 11, 2, GCS 17, 163; 166.

${ }^{9}$ Por. tamże 11, 3, GCS 17, 167.

${ }^{10}$ Por. Dal Covolo, Chiesa - società - politica, s. 56.

${ }^{11}$ Por. Clemens Alexandrinus, Quis dives salvetur 11, 4, GCS 17, 167.

${ }^{12}$ Por. tamże 12, 2-4; 18, 5, GCS 17, 167; 171.

${ }^{13}$ Por. tamże 15, 2-3, GCS 17, 169.

${ }^{14}$ Por. tamże 12, 5, GCS 17, 167.

${ }^{15}$ Por. tamże 13, 1-5, GCS 17, 168.
} 
posiadanych ${ }^{16}$, uwolnić się od przywiązania $(\sigma v \mu \pi \alpha ́ \theta \varepsilon \imath \alpha)$ do bogactw, od nadmiernego pragnienia ( $\dot{\varepsilon} \pi \imath \theta \mu \hat{i} \alpha)$ ich posiadania, od niepokoju ( $\pi \tau o i ́ \alpha)$, udręki

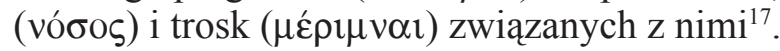

Dobra materialne same w sobie zostają postawione przez Aleksandryjczyka na terenie neutralnym. Są to tzw. ódió $\varphi o \rho \alpha^{18}$, czyli rzeczy obojętne: ani dobre, ani złe. Osądowi podlega natomiast ten, kto może używać tych dóbr dobrze albo źle, a mianowicie ludzki umysł, który posiada osąd rzeczy i wolną wolę w ich używaniu ${ }^{19}$. U Klemensa liczne są wypowiedzi, w których dobra materialne zostają ukazane jako posiadające wyraźnie pozytywny potencjał: są one przygotowane przez Boga na użytek ludzi; są narzędziem, którego można używać we właściwy sposób; narzędziem, za pomocą którego można również pomóc bliźnim ${ }^{20}$. Ważne jest tu jednak praktyczne pouczenie naszego Autora, mówiące, iż to bogaty powinien sam szukać tych, co są w potrzebie, a nie czekać, aż go ubodzy znajdą ${ }^{21}$. Jeśli natomiast chodzi o korzystanie z dóbr, częstym zaleceniem Klemensa jest cnota umiarkowania

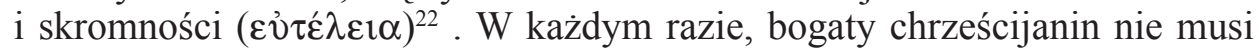
pozbywać się swoich dóbr, ale nauczyć się ich właściwego używania ${ }^{23}$. Aleksandryjczyk odwołuje się ponadto do jednego z Jezusowych błogosławieństw: „Błogosławieni ubodzy w duchu (oi $\pi \tau \omega \chi$ oì $\tau \hat{\omega} \pi v \varepsilon v ́ \mu \alpha \tau)$ )" (Mt 5, 3) ${ }^{24}$, i co ciekawe, wyjaśnia to wyrażenie w odniesieniu do człowieka zamożnego. Otóż „ubogi w duchu” to ten, kto posiada bogactwo jako dar Boży; za jego pomoca wysławia Boga; wie, że posiada te rzeczy raczej dla dobra bliźnich, niż dla siebie; nie jest niewolnikiem tego, co posiada; nie nosi tych dóbr w swoim sercu; a jeśliby kiedyś utracił te rzeczy, będzie umiał znieść pogodnie tę stratę, tak jak i radośnie przyjął posiadanie tych rzeczy ${ }^{25}$. Oczywiście, aby sprostać tym wymaganiom, bogaty chrześcijanin musi uciekać się do środków nadprzyrodzonych: modlitwy, praktykowania cnót i kierownictwa duchowego ${ }^{26}$.

Natomiast potępieni zostają przez Klemensa tacy bogacze, którzy namiętnie przywiązani są do swych bogactw, co zostaje określone jako noszenie bogactwa, czy posiadłości w duszy i w sercu; tacy, którzy pomnażają posiadłości

\footnotetext{
${ }^{16}$ Por. tamże 14, 5-6, GCS 17, 169.

${ }^{17}$ Por. tamże 11, 2, GCS 17, 166.

${ }^{18}$ Jest to termin i idea pochodzenia stoickiego, por. SVF III, fr. 117-118, ed. I. ab Arnim, Lipsiae 1903, 28.

${ }^{19}$ Por. Clemens Alexandrinus, Quis dives salvetur 14, 4; 15, 3, GCS 17, 168-169.

${ }^{20}$ Por. tamże 14, 1-3; 15, 4-5, GCS 17, 168-169.

${ }^{21}$ Por. tamże 31, 7, GCS 17, 180.

${ }^{22}$ Por. Clemens Alexandrinus, Paedagogus III 6, 35, 3; 7, 38, 1; 38, 3; 39, 1, ed. C. Mondésert

- Ch. Matray - H. I. Marrou, SCh 158, Paris 1970, 78, 84 i 86.

${ }^{23}$ Por. Clemens Alexandrinus, Quis dives salvetur 27, 1, GCS 17, 177.

${ }^{24}$ Oczywiście wersja Mateusza bardziej odpowiadała Klemensowi, niż paralelny tekst Łukasza $(6,20)$ : „Błogosławieni ubodzy”.

${ }^{25}$ Por. Clemens Alexandrinus, Quis dives salvetur 16, 3, GCS 17, 170.

${ }^{26}$ Por. tamże 40, 6 - 41, 2, GCS 17, 187.
} 
bez miary; którzy patrzą tylko, by mieć coraz więcej ${ }^{27}$; tacy, którzy ukrywają i trzymają tylko dla siebie dobra tego świata, odmawiając ich potrzebującym ${ }^{28}$. Aleksandryjczyk potępia w ogóle używanie rzeczy zbytkownych i wykraczających po za to, co potrzebne do życia ${ }^{29}$. Ciekawostka jest tu jego kaśliwa uwaga, dotycząca używania przez bogaczy nocników i pojemników na śmiecie $z$ kosztownych materiałów ${ }^{30}$. Według naszego Autora, bogactwo źle zarządza-

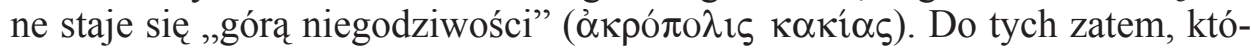

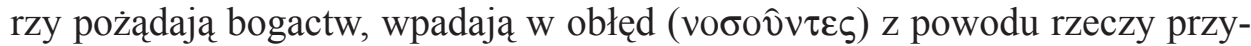

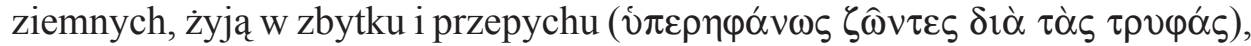
należy odnieść Jezusowe słowa: „Bogaci z trudem wejdą do królestwa niebieskiego"31, a nie do bogatych rozumianych wyłącznie jako posiadaczy rzeczy zewnętrznych. Nasz Autor podaje tu zresztą następujący argument: zbawienie człowieka nie może się opierać na rzeczach zewnętrznych, ale na cnotach duszy, na wierze, nadziei, miłości Boga i bliźniego, łagodności i skromności ${ }^{32}$.

Ton wypowiedzi Aleksandryjczyka mógł uspokoić nieco ludzi bogatych i wlać w ich serca nadzieję. Choć zostały im postawione zdecydowane i konkretne wymagania co do używania bogactw ${ }^{33}$, i nie oszczędzono im słów przestrogi, to jednak otrzymali oni zapewnienie, iż są wręcz potrzebni w społeczeństwie, a ich dobra mogą stać się narzędziem dobrych uczynków. Możliwość dobrego użycia majętności Klemens zdaje się podkreślać nie mniej, niż ich niebezpieczeństwo. Być może jego odpowiedź na nasz problem jest w pewnej mierze kompromisem między radykalizmem Ewangelii a realiami życia ${ }^{34}$. Należy jednak zapytać, czy taki kompromis nie jest czasami uzasadniony. Aleksandryjczyk dał na pewno odpowiedź przeniknięta głębokim humanizmem, wykazał dużą wrażliwość na ludzkie potrzeby ${ }^{35}$. Na taką odpowiedź mógł mieć ponadto wpływ kontekst historyczny. Wspomnieliśmy już wcześniej, że w Aleksandrii żyło wówczas wielu chrześcijan zamożnych. Ponadto w czasach tych (2 poł. II w.) osłabło już oczekiwanie rychłego powrotu Pana. Uwaga chrześcijan zwraca się teraz bardziej na stosunek do rzeczywistości ziemskich, wśród których życie będzie się nadal toczyćc ${ }^{36}$. Wydaje się,

\footnotetext{
${ }^{27}$ Por. tamże 17,1, GCS $17,170$.

${ }^{28}$ Por. tamże 31, 6; 37, 5-6, GCS 17, 180 i 184.

${ }^{29}$ Por. Clemens Alexandrinus, Paedagogus II 3, 35, 1 - 38, 3, ed. C. Mondésert - H. I. Marrou, SCh 108, Paris 1965, 76-82.

${ }^{30}$ Por. tamże II 3, 39, 2, SCh 108, 84.

${ }^{31}$ Por. tamże II 3, 38, 5, SCh 108, 84.

${ }^{32}$ Por. Clemens Alexandrinus, Quis dives salvetur 18, 1, GCS 17, 171.

${ }^{33} \mathrm{Nie}$ bez racji M. Todde i A. Pieri (Retto uso delle ricchezze nella tradizione patristica, Milano 1985, 58) stwierdzają: „Clemente [...] facendo concessioni sul possesso, non fa concessioni sull'uso".

${ }^{34}$ Por. Mara, Ricchezza e povertà, s. 43.

${ }^{35}$ Por. Todde - Pieri, Retto uso delle ricchezze, s. 58-59; Paternoster, „Quis dives salvetur?”, s. 258

${ }^{36}$ Por. Mara, Ricchezza e povertà, s. 43.
} 
iż Klemens wykazał głęboką świadomość tego, że chrześcijaństwo nie jest sektą, ale religią uniwersalną ${ }^{37}$, jest ofertą zbawienia zwróconą do wszystkich, i że chrześcijaństwo w swojej „ekspansji” będzie potrzebowało ludzi wszystkich klas i stanów, także bogatych.

2. Orygenes. Także ten największy nauczyciel Szkoły Aleksandryjskiej w Komentarzu do Mateusza podejmuje interpretację epizodu o bogatym młodzieńcu (Mt 19, 16-26). Kluczowe słowa tego fragmentu: „Jeśli chcesz być doskonały, idź, sprzedaj, co posiadasz i rozdaj ubogim” wyjaśnia on na dwa sposoby: najpierw podaje ich interpretację dosłowna, później - tak jak Klemens - alegoryczną. W tej pierwszej Aleksandryjczyk dostrzega pewne trudności i wysuwa watpliwości dotyczace krytyki tekstu Ewangeliii ${ }^{38}$, ostatecznie jednak zdaje się ustanawiać ścisły związek, pomiędzy doskonałością i związanym z nią przykazaniem miłości bliźniego, a posiadaniem bogactw ${ }^{39}$. Pogodzenie jednego z drugim jest niestety niemożliwe, szczególnie, jeśli ktoś posiada wiele majętności. Sprawdzianem autentycznej miłości bliźniego jest właśnie gotowość do rozdania swych dóbr ubogim ${ }^{40}$. Sam Autor zdaje sobie sprawę, że są to twarde słowa, ale mimo tego zachęca, by nie lekceważyć dosłownego sensu Jezusowej wypowiedzi. To Jego radykalne żądanie znajduje swe poparcie nade wszystko w przykładzie pierwotnej gminy jerozolimskiej, opisanej w Dziejach Apostolskich (por. 2, 44-47; 4, 32-37; 5, 1-10), w której istniała wspólnota dóbr ${ }^{41}$.

Następnie Orygenes przechodzi do alegorii. Podobnie jak dla poprzednika,

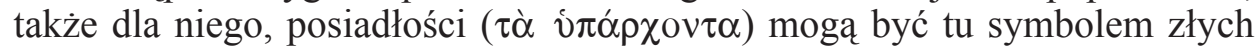
uczynków, a przede wszystkim nieuporządkowanej żądzy bogactwa i sławy. Także tu nakaz Jezusa: „Idź, sprzedaj wszystko, co masz” oznacza uwolnienie serca od tych złych skłonności. Sam Orygenes - skądinąd rozmiłowany w szukaniu głębszego znaczenia Pisma Świętego - ma jednak dystans do tej alegorii. Przyznaje, iż takie wyjaśnienie wydaje mu się zbyt „naciągane”. Problematyczna jest tu przede wszystkim kwestia, jak rozumieć nakaz, aby mienie, symbolizujące bagaż wad i grzechów, rozdać ubogim. Ponadto Aleksandryjczyk nie bardzo wierzy, by człowiek, który rzeczywiście nie uwolni się od bogactwa tego świata, mógł się również łatwo wyzbyć swych grzesznych

${ }^{37}$ Samo dzieło Quis dives salvetur - jak słusznie zauważa M.G. Bianco (Clemente Alessandrino, s. 17) - jest nie tylko dziełem na temat dóbr materialnych, ale także na temat uniwersalizmu chrześcijaństwa.

${ }^{38}$ Por. Origenes, Commentarius in Matthaeum XV 14, ed. E. Klostermann, GCS 40, Leipzig 1935, 385-389.

${ }^{39}$ Por. Dal Covolo, Chiesa - società - politica, s. 63.

${ }^{40}$ Por. Origenes, Commentarius in Matthaeum XV 14, GCS 40, 390. Część tego fragmentu opiera się jedynie na tłumaczeniu łacińskim komentarza, wobec którego wysuwano wiele zarzutów. Jednak w tym miejscu fragment łaciński doskonale harmonizuje z całym kontekstem.

${ }^{41}$ Por. tamże XV 15, GCS 40, 391-395. 
namiętności ${ }^{42}$. Z kolei komentując Jezusową przestrogę: „Bogaty z trudnością wejdzie do królestwa niebieskiego", nasz Autor odnosi ją zarówno do bogatego w znaczeniu dosłownym, jak i bogatego w znaczeniu alegorycznym, tzn. uwikłanego w grzeszne namiętności. Tak jednemu, jak i drugiemu, trudno będzie osiaggnąć zbawienie; trudność ta nie oznacza wszelako niemożności. Otóż bogaty może wejść do Królestwa niebieskiego tylko dzięki wszechmocy Bożej, gdyż dla Boga możliwe są wszystkie rzeczy. Orygenes kończy jednak swój wywód enigmatycznie: w jaki sposób Bóg czyni możliwe zbawienie bogatego, wie tylko On sam, Jego Syn i ten, komu Syn zechce objawićc ${ }^{43}$.

Widzimy więc, że stanowisko Orygenesa jest o wiele bardziej radykalne niż Klemensa. Ton jego wypowiedzi jest - w przeciwieństwie do poprzedni$\mathrm{ka}-$ zasadniczo niepokojący dla człowieka bogatego ${ }^{44}$. Orygenes przemilcza pozytywy, mogące wynikać z właściwego używania dóbr. Nie daje też bogatym praktycznych wskazówek, jak podchodzić do rzeczy materialnych i jak nimi dysponować; jedyną nadzieją bogatego jest Boża wszechmoc. Nawet interpretacja alegoryczna potwierdza niejako osąd, wynikający z interpretacji dosłownej: bogactwa materialne są przyczyną grzechów; ci, którzy chcą pójść za Chrystusem, muszą je zostawić ${ }^{45}$. Podsumowując myśl Orygenesa, trzeba w ogóle powiedzieć, że stawia on epizod o bogatym młodzieńcu w zupełnie innej perspektywie niż Klemens. U Orygenesa jest to perspektywa ascetyczna - w centrum zostaje postawiony problem dążenia człowieka do osobistej doskonałości ${ }^{46}$.

3. Dydym Ślepy. Ten niewidomy nauczyciel, żyjący w Aleksandrii w IV wieku, nie porusza wprawdzie naszego zagadnienia w sposób systematyczny, jak Klemens, ale w kilku miejscach swoich komentarzy (głównie do Ksiag Hioba i Koheleta) wyraża krótko swoją myśl, odnośnie dóbr materialnych. Generalnie Dydym klasyfikuje je - tak jak stoicy ${ }^{47}$ - jako rzeczy obojętne $\left(\alpha \dot{\delta} \delta \hat{\imath}(\varphi \circ \rho \alpha)^{48}\right.$, czyli same w sobie ani dobre, ani złe; można ich jedynie dobrze

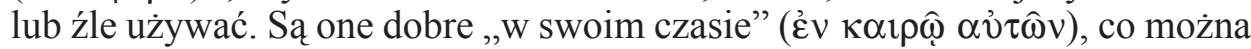
rozumieć jako „użyte we właściwy sposób, zgodnie ze swoim przeznaczeniem"49. Aleksandryjczyk waha się jednak nazywać je wprost „dobrami”.

${ }^{42}$ Por. tamże XV 18, GCS 40, 399-403.

${ }^{43}$ Por. tamże XV 20, GCS 40, 405-409.

${ }^{44}$ Por. Dal Covolo, Chiesa - società - politica, s. 66.

${ }^{45}$ Por. Mara, Ricchezza e povertà, s. 48.

${ }^{46}$ Por. Dal Covolo, Chiesa - società - politica, s. 66.

${ }^{47}$ Por. wyżej przypis 18 .

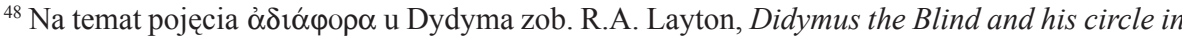
late-antique Alexandria. Virtue and narrative in Biblical scholarship, Chicago 2004, 58-59. Amerykański uczony nie zwraca jednak uwagi na pozytywny potencjał, który Aleksandryjczyk dostrzega w dobrach materialnych.

${ }^{49}$ Por. Didymus Alexandrinus, Commentarius in Hiob 42, 8-13, ed. A. Henrichs, Papyrologische Texte und Abhandlungen (= PTA) 1, Bonn 1968, 134; tenże, Commentarius in Ecclesiasten 


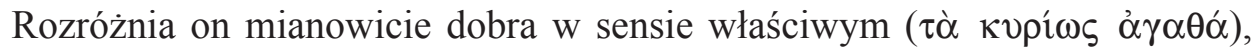
to znaczy dobra duchowe, cnoty moralne, oraz to, co nie jest dobrem w sensie właściwym, a tylko jest powszechnie uważane za takie ( $\tau \grave{\alpha} v \varepsilon v o \mu \imath \sigma \mu \varepsilon ́ v \alpha$

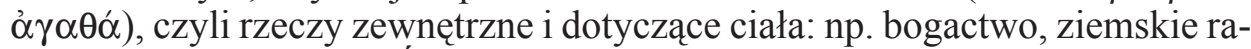
dości, zdrowie, $\operatorname{uroda}^{50}$. Świadomy takiej hierarchii, Dydym podkreśla, że bogactwo materialne jako takie nie daje prawdziwego szczęścia $(\varepsilon v ̉ \delta \alpha \imath \mu o v i \alpha)^{51}$.

Komentując Księgę Koheleta nasz Autor staje między innymi przed wersetami: „Dla każdego też człowieka, któremu Bóg dał bogactwo i majętność, i któremu pozwala z nich żywić się i wziąć swoją część oraz cieszyć się przy swoim trudzie - to Bożym jest darem” (Koh 5, 18) oraz: „Bo też, że człowiek je i pije, i cieszy się szczęściem przy całym swym trudzie - to Boży dar" (Koh $3,13)$. W tym miejscu mógł pojawić się dylemat, czy bogactwo, a szczególnie to używane dla siebie samego, można w ogóle nazwać Bożym darem. I jest znamienne, że Dydym nie ucieka się od razu do alegorii, ale pozostaje najpierw przy interpretacji dosłownej: bogactwo zostało dane człowiekowi, by z niego korzystał i cieszył się nim. Oczywiście Aleksandryjczyk przyznaje, że nie są to najwyższe i duchowe dary, ale jednak dary pochodzące od Boga, dary Jego opatrzności, dary które można nazwać drugorzędnymi czy dodatkowymi. Podaje on też pewne zastrzeżenie: jest to dar Boga, jeśli człowiek żywi się ze swych dóbr do syta; jeśli używa ich zgodnie z ich zasadniczym

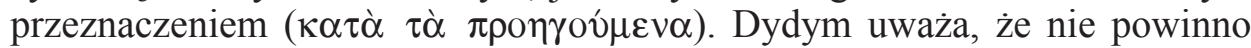
się w ogóle nazywać bogatym człowieka, który używa swych dóbr na rzeczy

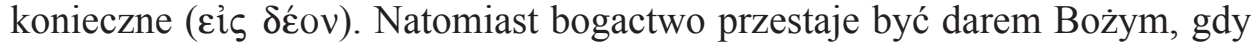
człowiek korzysta z niego ponad to, co niezbędne. „Bogaczem” w negatywnym tego słowa znaczeniu zostaje nazwany człowiek, który używa bogactwa dla przyjemności zmysłowych ${ }^{52}$. Jako przykłady złego wykorzystania i podejścia do dóbr materialnych Dydym wymienia ponadto poczucie wyższości z powodu swego majątku ${ }^{53}$, czy też organizowanie zbytkownych imprez dla próżnej chwały ${ }^{54}$.

167, 11-14, ed. J. Kramer, PTA 13, Bonn 1970, 50; tamże 82, 28 - 83, 3, ed. M. Gronewald, PTA 22, Bonn 1977, 90.

${ }^{50}$ Por. tenże, Commentarius in Hiob 247, 15-18, ed. U. Hagedorn - D. Hagedorn - L. Koenen, PTA 3, Bonn 1968, 68; tenże, Commentarius in Ecclesiasten 150, 3-14, PTA 13, 12; tenże, Commentarius in Hiob 42, 8- 11, PTA 1, 134.

${ }^{51}$ Por. tenże, Commentarius in Ecclesiasten 335, 20-26, ed. G. Binder - L. Liesenborghs, PTA 9, Bonn 1969, 98; tenże, Commentarius in Psalmos 197, 28-30, ed. M. Gronewald, PTA 8, Bonn 1969, 258. Również w tej kwestii Dydym zgadza się z nauką stoików, zob. SVF III, frag. 119 i 122, s. $28-29$.

${ }^{52}$ Por. Didymus Alexandrinus, Commentarius in Ecclesiasten 163, 9 - 164, 6, PTA 13, 38-40; tamże 83, 29 - 85, 12, PTA 22, 94-100. Na temat ludzi rozmiłowanych w przyjemnościach i żyjących w luksusie zob. również: tenże, Commentarius in Hiob 255, 32 - 256, 24, PTA 3, 90-92.

${ }^{53}$ Por. tenże, Commentarius in Ecclesiasten 166, 23-26, PTA 13, 48; tamże 335, 26, PTA 9, 98.

${ }^{54}$ Por. tenże, Commentarius in Psalmos 17, 1-6, ed. L. Doutreleau - A. Gesché - M. Gronewald, PTA 7, Bonn 1969, 64. 
Ważne jest jednak, że nasz Autor mówi konkretnie o możliwości spełniania dobrych uczynków za pomocą bogactw: dobrodziejstwa wobec bliźnich, czy też materialne wspieranie ludzi obdarzonych mądrością, a więc wspomaganie dobra duchowego ${ }^{55}$. Kolejne pozytywne światło zostaje rzucone na dobra materialne, gdy Aleksandryjczyk stwierdza:

„Obfitość bogactwa u tego, kto umie się nim właściwie posługiwać, przyczy-

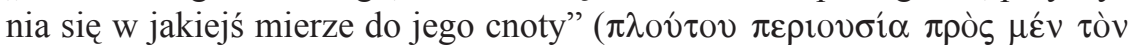

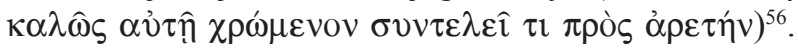

Bogactwo więc nie tylko, że nie musi przynosić człowiekowi szkody na duszy, ale może jeszcze nawet sprzyjać jego dobru duchowemu. Oczywiście cały akcent spoczywa na sposobie korzystania z dóbr. Dydym natychmiast uzupełnia, że bogactwo samo w sobie do cnoty nie wnosi nic ${ }^{57}$. Możliwość pozytywnego wpływu dóbr zewnętrznych, w tym także środków materialnych, na cnotę moralną, to idea zaczerpnięta $z$ tradycji platońsko-arystotelesowskiej ${ }^{58}$. Trzeba powiedzieć, że tak pozytywne spojrzenie na dobra materialne jest rzadkie w okresie patrystycznym. Podobnym tonem Dydym wypowiada się komentując Ps 20, 7: „Obdarzysz go błogosławieństwem na wieki wieków”. Oczywiście stwierdza on najpierw, iż majętność jako taka nie stanowi błogosławieństwa wiecznego, gdyż niszczeje i przemija ${ }^{59}$. Nawiązując do 1 Tm $6,17-19$, dodaje jednak, że jeśli ktoś za pomocą swego bogactwa spełnia dobre uczynki, to jego błogosławieństwo trwa na wieki, i kończy lakonicznym stwierdzeniem:

„To, co zostało uczynione przy pomocy bogactwa, pozostaje niezniszczalne”

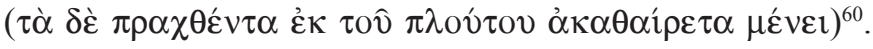

W tej perspektywie dobra materialne jawią się jako wspaniałe narzędzie zdobywania zasług na życie wieczne, otrzymują nareszcie swój wymiar eschatologiczny. $Z$ takim przedstawieniem problemu i z taką retoryką Dydym mógł rzeczywiście trafić do ludzi bogatych.

Właściwe kryterium w ocenie dóbr materialnych stanowi więc dla Dydyma ich sposób używania przez człowieka. Nawet samo bycie bogatym, to kwestia używania, a nie posiadania bogactw. Niewidomy nauczyciel jest daleki od radykalizmu Orygenesa; jego stanowisko jest bliższe Klemensowi. Podobnie jak ten, prezentuje on zasadniczo pozytywne spojrzenie na dobra materialne. Więcej mówi o możliwości ich dobrego użycia, niż o niebezpieczeństwie, któ-

${ }^{55}$ Por. tenże, Commentarius in Ecclesiasten, 224, 6-9, ed. J. Kramer - B. Krebber, PTA 16, Bonn 1972, 92.

${ }^{56}$ Tenże, Commentarius in Hiob 22, 5-7, PTA 1, 82.

${ }^{57}$ Por. tamże 22, 7-9, PTA 1, 82.

${ }^{58}$ Por. np. Aristoteles, Ethica Nicomachea I 8, 1099ab, ed. F. Susemihl - O. Apelt, Bibliotheca Scriptorum Graecorum et Romanorum Teubneriana, Lipsiae ${ }^{3} 1912$, 15; zob. Henrichs (ed.), Didymos der Blinde, Kommentar zu Hiob (Tura-Papyrus), PTA 1, s. 83, przypis 52.

${ }^{59}$ Por. Didymus Alexandrinus, Commentarius in Psalmos 18, 2-3, PTA 7, 68.

${ }^{60}$ Tamże 18, 4-8, PTA 7, 68. 
re ze sobą niosą. Wydaje się, iż mocno wierzy w to, że człowiek bogaty może uczynić z nich sprzymierzeńca swej duszy. Jest wyrazicielem chrześcijańskiego uniwersalizmu, dzięki któremu również ludzie zamożni mogli czuć się potrzebni chrześcijaństwu. Na stanowisko Dydyma miał niewątpliwie wpływ także kontekst historyczny. Jak wiadomo, w IV wieku chrześcijaństwo uzyskało pełną swobodę i stało się oficjalną religią cesarstwa. Ten nowy status, jaki otrzymało, przyczynił się z pewnością do jeszcze dojrzalszego spojrzenia na kwestie społeczno-ekonomiczne. Pozostaje jednak faktem, że nie każdy pisarz IV wieku miał tak szerokie i optymistyczne spojrzenie na dobra materialne.

\section{CHRISTIAN TOWARDS MATERIAL GOODS. REFLECTION OF THE ALEXANDRIAN SCHOOL FROM CLEMENS TO DIDYMUS THE BLIND}

\section{(Summary)}

The article presents how three great Alexandrian writers (Clemens, Origen and Didymus the Blind) estimated possession of material wealth. The first of them in Quis dives salvetur? assures Alexandria's rich Christians that they also can achieve salvation, although under certain circumstances. Clemens explains Jesus' words to the rich young man: "Sell everything you have, and give to the poor" (Mk 10,21) allegorically. This order means that the wealthy should remove from the heart attachment to material goods and extirpate all passions which are bound up with them. The author wonders rhetorically: Who will help the poor, if we all will be devoid of material goods? Clemens regards earthly riches as things which are in themselves indifferent (adiafora). Christians should use them in moderation and for God's glory. Besides, they must look for the poor and help them.

Origen, in his turn, first interprets literally the pericope of the rich young man (Mt 19, 16-26). Considering the question from the ascetic perspective, the great writer thinks that it's impossible to reconcile riches with Christian perfection. Origen accepts also the allegorical interpretation, according to which ,possessions" symbolize evil passions and deeds. However to him such explanation seems to be overdone. Besides, in his opinion, the man who didn't give up his riches, will never be able to free himself from evil passions. Therefore, according to Origen, it's hard for the wealthy to achieve salvation. That will be possible only thanks to God's omnipotence. So Origen's words could infuse worry and uncertainty into the rich.

Didymus, the last teacher of the Alexandrian school, following the Stoics and Clemens, defines material goods as adiafora. He adds also that these aren't goods in the proper sense. Moreover, the author admits that riches are a secondary gift of God. Obviously they are that, if one uses them as far as they are necessary. But the most important aspect is that Didymus emphasizes resolutely a positive potential of material wealth. By means of it one may help other people, including for example the support of the sage. Riches if used right - asserts the author 
following the Platonic and Aristotelian tradition - can contribute to moral virtue of their owner. This way material goods become an instrument through which one may merit eternal life. Surely with such rhetoric Didymus could impress the rich. We must admit that his stance was due to the historical context as well, since Christianity became in the IV century the official state religion. Its new condition certainly contributed to a more mature look at social and economic questions. 
